\title{
IMPACT OF MARKET ORIENTATION ON FIRM PERFORMANCE; THE MEDIATING ROLE OF INNOVATION STRATEGIES IN EXCELLENCE AWARDED CORPORATE SECTOR
}

\author{
Khawar Naheed \\ Assistant Professor; Bahauddin Zakariya University, Multan, Pakistan \\ Muhammad Sadiq Shahid (corresponding author) \\ Assistant Professor, Bahauddin Zakariya University, Multan \\ Muhammad Aamir \\ Bahauddin Zakariya University, Multan \\ Badar Latif \\ Research Scholar; Department of Commerce B. Z University, Multan
}

\begin{abstract}
Innovation strategy and market orientation is vital for firm performance and competitive advantage. The survival of organizations dependent on its innovation strategies regarding the product, process and technological development and market orientation in order to increase firm performance. Innovation strategies. Market orientation helps in giving direction to the organization by providing superior value to the customers. The market orientation from organization perspective makes the customer as the focal point that influence on its performance. These main objectives of this study are; to examine the direct relationship between market orientation and firm performance and examine the indirect relationship of innovation strategies (mediation) between market orientation and firm performance. Using quantitative technique, this study collected questionnaires from 240 employees and managers working in corporate excellence awarded organizations. The data was analyzed in SPSS and PLS-SEM for analysis. The results indicated that market orientation has direct relationship with firm performance. The results also confirmed the indirect effect of innovation strategies between market orientation and firm performance. This indirect effect indicated that innovation strategies partially mediate between market orientation and firm performance. The finding of this study suggest that the corporate sector top managers and policy makers should adopt and implement the innovation strategy for the long term success and gain superior performance.
\end{abstract}

Keywords: Innovation strategy, Firm performance, Market orientation

\section{Jel Classification: C38; C83; M31; Q13}

*The material presented by the author does not necessarily portray the view point of the editors and the management of the Ilma University - Formerly IBT

1. Khawar Naheed

2. Muhammad Sadiq Shahid (corresponding author)

3. Muhammad Aamir

4. Badar Latif

\footnotetext{
: khawarnaheed@bzu.edu.pk :sshahidmalik@bzu.edu.pk

: maamirbzu@yahoo.com

: badarlatif@gmail.com
}

OILMA-JBS is published by the Ilma University - Formerly IBT

Main Ibrahim Hydri Road, Korangi Creek, Karachi-75190, Pakistan 


\section{INTRODUCTION}

Increasing attention on innovation and creativity is being rewarded success for the competitive advantage and firm performance. Innovation is the main driver of the firm product, process, and performance (Jenssen, 2004). Several studies have focused on innovation strategies adapted by firms in order to increase performance and competitiveness of an organization (e.g., Akman \& Yilmaz, 2008; Dangayach \& Deshmukh, 2004). These studies have found a positive relationship between innovative strategies and improved performance particularly in high technology firms of corporate sector. In the age of globalization, innovation strategy regarding organization internal and external environment is plays an essential role for achieving efficiency particularly for excellence for awarding organizations (Dangayach \& Deshmukh, 2004). Organizations develop their innovation strategies according to dynamic and competitive environment that helps in the development of products, reduction of product cost, and enhancement of performance.

There are studies that have found a positive association between market orientation and firm performance (e.g., Länsiluoto, Joensuu-Salo, Varamäki, Viljamaa, and Sorama, 2018). The study of Micheels and Gow, (2012) argued that market orientation is an important ended with increasing firms 'performance of the company. Therefore, innovation strategies and market orientation help organization to survive in the market through gaining competitive advantage and improving their performance (e.g., Chandra, 2009;; Kohli \& Jaworski, 1990; Länsiluotoet al., 2018; Najib, Kartini, Suryana, \& Sari, 2017).

The best example that used innovation strategies in their product and process and technological innovation and life cycle to gain and sustain in the competitive environment is high technology sector (Nambisan, 2002). Innovation strategy is essential for successful organization (Guan et al., 2009; Lendel \& Varmus, 2011) because it helps in increasing firm performance, reducing the environmental impact (Wei \& Wang, 2011) and finding new opportunities (Lendel \& Varmus, 2011). Innovation strategy brings new ideas and engages the sector into creative process and experimentation and these changes bring new product, process and technologies in the market and improve firm performance.

Previous studies highlighted the vital role of market orientation on firm performance as it gives direction to the organization to focus on the vision that in turn creates superior value for the customer (e.g., Kohli \& Jaworski, 1990; Länsiluoto et al., 2018; Najib et al., 2017;). The concept of market orientation explains the organizational culture that effectively produces the essential behaviors that generate higher value for customers and continuous valuable performance for an organization (Narver \& Slater, 1990). The organization can bring positive changes through bringing appropriate skills and sensitivity for the organization which enhanced the customer needs which is possible through market orientation (Gronroos, 1990; Ruekert, 1992). Previous studies developed the understanding and investigated the direct relationship of market orientation and innovation strategies (e.g., Guann et al., 2009; Kylaheiko et al., 2013) and also on innovation strategies and firm performance (e.g., Bayraktar, Hancerliogullari, Cetinguc, \& Calisir 2016; Haefner, Naomi \& Palmié, Maximilian, 2017). Howe ever, there is lack of studies that have focused on the indirect effect of innovation strategies between the relationship of market orientation and performance. The recent study fills this gap by considering innovation strategies as a mediator between market orientation and firm performance. 
Innovation strategy is essential in order to increase firm performance. Mangers are still facing problem in increasing firm performance, which can be overcome by focusing on the antecedents of firm performance (Maltz et al., 2003; Moullin, 2007). In addition, the previous literature focused on the direct effect of innovation strategy on firm performance (e.g., Bayraktar, Hancerliogullari, Cetinguc, \& Calisir 2016; Haefner, Naomi \& Palmié, Maximilian, 2017). This study argued that innovation strategy is important in the process of increasing firm performance with help of market orientation, which in turn leads to competitive advantage (Spencer et al., 2009). Based on this gap, this study has two research objectives; first, it examines the direct effect of market orientation on firm performance; second, it examines the mediation of innovation strategy between market orientation and firm performance.

\section{LITERATURE REVIEW}

\subsection{Innovation strategy}

Innovation strategy is defined as "the extent to which a firm values and promotes innovation across the organization" (Wei \& Wang, 2011). Innovation strategy monitors the organization to meet their objectives, make decision making regarding resources utilization, value creation and enhancement of competitive advantage. In addition, innovation strategy guides the organization in aggregate and supportable manners, which best supported the organization to meet their objectives (Dodgson et al., 2008). These strategies promote new tools, production, management practices that minimize environmental cost related to organization activities and it improved the efficiency of resources (Mariadoss, Tansuhaj \& Mouri, 2011). Innovation has discussed in many studies with various dimensions, including radical or incremental (Tidd \& Bessant, 2009). These radical or incremental innovation further classified in product, process, marketing or organizational innovation (Jenssen \& Nybakk, 2009; Jenssen \& Randoy, 2002; Jenssen \& Randoy, 2006). Previous studies has discussed the importance and implementation of innovation because it indicates the distinguished influence of innovation types at various level of organization (Jenssen \& Nybakk, 2009; Jenssen \& Asheim, 2010). These studies also mentioned the relationship between innovation and firm performance and argued that organization achieved success for longer period of time with innovation strategies (Bayraktar et al., 2016; Haefner et al., 2017; Hult, 2004; Schumpeter, 1934; Wheelwright \& Clark, 1992).

Innovation has been studied with its five dimensions namely aggressive, analyzer, defensive, futuristic, proactive, and risk taking in several fields (Tidd \& Bessant, 2009) because it has direct effect on product, process, and market development which increase the performance of organization (Jenssen \& Nybakk, 2009; Jenssen \& Randoy, 2006). Extant literature haves highlighted the significance of innovation for organizational success (Jenssen \& Asheim, 2010). The relationship of innovation and firm performance has a very long history (Schumpeter, 1934, 1942). Previous studies showed that innovative organizations are more successful than non-innovative organizations (Calantone et al., 2002; Deshpande, Farley \& Webster, 1993; Gronhaug \& Kaufmann, 1988). In addition, several studies have suggested that innovation has risky for the positive outcome and it can be cause of failure for an organization through new product innovation (Cooper, 2001). Furthermore, the outcome of the innovation varies and is not consistent (West \& Farr, 1989). Some research has described that their relationship is $U$ shaped, which are variant with the firm performance (Cooper \& Brentani, 1991). Therefore, it is important for firms to focus on innovation strategies to 
maintain their share in the market and increase their performance. There are researchers that argued that firm can gain high performance due to several innovative practices/strategies (Deshpande \& Webster, 1989). Innovation strategy of firms focused on different areas (Peasrson, 1990; Zahra \& Das, 1993). These areas are related to cost reduction, product development, quality improvement. In addition, innovation strategy focuses on six innovations characteristic: aggressiveness, analyzer, defensive, futuristic, pro-active and risktaking for successful innovation (Crespell \& Hansen, 2008). These characteristics are concentrated into three dimensions (1) product (2) process (2) business system (4) expenditure on research and development.

\subsection{Aggressive Strategy}

Aggressive strategy associated with environmental scenarios which is linked with the advantages of the firm for the competitive advantage, first mover advantage, developed radical innovation and encouraged the innovation projects to get high level of return (Akman \& Yilmaz, 2008). Aggressive strategy pursue the organization to manage the resources efficiently that can improved the worth of market share, organizational value and efficient controlled on the cost reduction to get a better profit (Venkatraman, 1989). But if the organization implement aggressiveness strategy without deliberate and understand their environment; without evaluating the risk and opportunities and compared this risk and opportunities to their organizational capability, they might be faced some serious failure or loss. Because aggressiveness strategy is directly related with organizational resources and directly effected on firm performance. It lead the organization to expend their product speedily, promote to innovation and competitive advantage (Akman \& Yilmaz, 2008)

\subsection{Analyzer Strategy}

Analyzer strategy has designated the comprehensive problem solving characteristics. It offers relevant information about environment, occasions and latest trend to the organization that enable opportunities exploitation (Entrialgo et al., 2000). Analyzer strategy focused on high quality of knowledge for firm to gather and data, because the higher position employee/ managers can evaluate these information to exploit the deficiency in future developments. In addition, they take some serious suitable actions to better their management practices in future developments and subsequently for the cost saving, quality assurance and time management (Love \& Irani, 2003). Therefore, analyzer strategy is precarious factor for the firm performance to sort innovation pronouncements (Entrialgo et al., 2000). In addition, analyzer strategy focused on the sources of information that helps in finding solution for the problems related with product, process, technology, management and performance of firm (Guan et al., 2009).

\subsection{Futuristic Strategy}

Futuristic strategy guides organization for long term planning and forecasting to exploit the opportunities (Chandy \& Tellis, 1998). Futurity strategy provides the wide range of interpretation, ideas and guides organization to bring market based changes (Akman \& Yilmaz, 2008). Organization should have long term viewpoint for their customer, competitor and environment (Vazquez, Santoz \& Alvarez, 2001). Because analyzer strategy can guide the organization for some indefinite occasions and provide the response to meet the future demands. These strategy exploit new ideas, opportunities which possible support for innovation (Jaworski \& Kohli, 1993). Futuristic strategy is necessary for the organization to 
persist constant with external environment variation and give quick response to these unpredictable changes for the rapid vibrant maintenance of firm performance (Kazaz \& Ulubeyli, 2009)

\subsection{Proactive Strategy}

Proactive strategy highlights the new window of opportunities for the organization which brings changes, innovation and developed the organization as well as environment by manipulating different opportunities (Droge, Calantone \& Harmancioglu, 2008). Because of these opportunities, organization adopt proactive strategy to get consideration of innovative products and new services for the customer at market and get superior profit (Wei \& Wang, 2011). These methods and strategies are pursue the organization for new product development, firm performance, better cost controller, improved R\&D and utilization of capacity (Menguc \& Auh, 2008) .

\subsection{Risk Taking Strategy}

Risk-taking is explained as the point of tolerance at which firm accept the risk infrequent failures (Jaworski \& Kohli, 1993). In addition, organizational performance is increasds without of taking risk that organization achieve performance without taking risk (Akman \& Yilmaz, 2008). It also proposed innovative ways, processes and methods without taking higher risk it could not be achieved the success (Jaworski \& Kohli, 1993; Akman \& Yilmaz, 2008). Risk taking strategy referred to the top managers and executives to take the risk for their firm growth and performance (Gupta, MacMillan \& Surie, 2004).

\subsection{Defensive Strategy}

Defensive strategy referred to the defensive attitude related to organization "Need to defend its current position in the marketplace" (Morgan \& Strong, 1998; Akman \& Yilmaz, 2008). These strategies has functional on those organization which have inadequate product variety (Miles \& Snow, 1978). In most cases, defensive strategy is used for improvement of product's quality measures, reducing cost and efficiency related measures (Venkatraman, 1989). This strategy effect on the firm performance but its effects are less than the proactive innovation strategy (Akman \& Yilmaz, 2008).

\subsection{Market Orientation}

Market orientation is demarcated by Narver \& Slater (1990) as "the organization culture that most effectively and efficiently creates necessary behaviors for the creation of superior value for buyers and thus, continuous superior performance for the business". Market orientation is essential element for organizational culture and also necessary for the innovation oriented environment. In addition to innovation, market orientation is important to get the success, it supports organizational culture and available resources in order to get innovation. These components are further categorized into three segments; customer orientation, competitor orientation and inter functional co-ordination. Customer orientation described that the firm understand their target customer to make value creation and superior performance (Narver \& Slater, 1990). Competitor orientation emphases on firm's ability to understand and analyzed its competitors and gives them response (Gatignon \& Xuereb, 1997). It can also be explained that it highlights the strong and weak point in short time period and potential to response according to their ability (Narver \& Slater, 1990). Inter- 
functional co-ordination, explain management coordination to fulfill and respond their customer needs (Mavondo, 2000).

An organizational resource facilitates organization to implement innovation strategies. The firm which has high capability of innovation can develop new capabilities that response to organizations resources and helps to survive in competitive environment (Hurley \& Hult, 1998). This important factor increases firm knowledge about external factors environment which in turn firms 'knowledge (Atuahene \& Ko, 2001).

\subsection{Customer Orientation}

Customer orientation defined as "a firm that has an ability to define, analyses, understand customer wants and response to this wants" (Gatignon \& Xuereb, 1997; Zhang \& Doll, 2001). Customer orientation has focused to the target customer of the organization sufficiently to make value to their customer (Narver \& Slater, 1990).

\subsection{Competitor Orientation}

Competitor orientation defined as "ability of firm to define, analyses competitors activities and to response to them" (Gatignon \& Xuereb, 1997). In competitor orientation, organization recognizes resilient and weak point about their challengers and planned the strategies to response the challenges (Narver \& Slater, 1990). These orientation consistently concentrated on the competitor products and services and ready to response with their own power of products (Mavondo, 2000).

\subsection{Inter-functional Co-ordination}

Inter functional co-ordination is defined as "an efficient factor in order to work departments coordinately, to informal department about customer needs and to be responsive to customers" (Kohli \& Jaworski, 1990). However, this factor does not only deals with one job, it also deals with the all the integration and usage of the resources of the firm that gives superior values to the customer (Narver \& Slater, 1990).

\subsection{Firm Performance}

Firm performance measured by various methods, It can be financial performance (profitability, return on investment), product performance (product reliability, number of unique product features) and market performance (market share, customer satisfaction) (Jones, Lanctot \& Teegen, 2000). Nowadays firms are greatly concentrated on firm performance. In addition, there are variety of techniques and methods which determines firm performance. Firm performance can be measured by two indicators; financial and operational indicators. Financial indicators are consisted on economic indicators and operational indictors are consisted on non-financial indicators such as quality, market shares, and utility, new product development (Venkatraman \& Ramanujam, 1986). For firm performance, two measures are very essential; growth measures and profit measures. Growth measure are consisted on sales growth and profit measures are consisted on return on assets (ROA) and return on sale (ROS) ( $\mathrm{Li} \& \mathrm{Ye}, 1999)$. Some studies have suggested that in some cases, internal and external strategy can be lead to firm performance, alongside with various performance measures. The relationship between firm performance and strategy is often beneficial and these relationships successfully lead to financial performance and steady the 
homogenous business environment (Jones, Lanctot \& Teegen, 2000). The firm performance can be improved by the organizational structure, planning, management system and information system that are associated with firm specific strategy (Miles \& Snow, 1994). Some definite strategy is planned for specific goals, objectives and actions and these measures are lead to firm performance (Donovan, 2009).

\subsection{Hypothesis Development}

$\mathbf{H}_{1}$ : Market orientation is positively related with innovation strategy.

$\mathbf{H}_{2}$ : Innovation strategy is positively related with firm performance.

$\mathbf{H}_{3}$ : Market orientation is positively related with Firm performance.

$\mathbf{H}_{4}$ : Innovation Strategy has mediation effect between market orientation and firm performance.

\subsection{Conceptual Model}

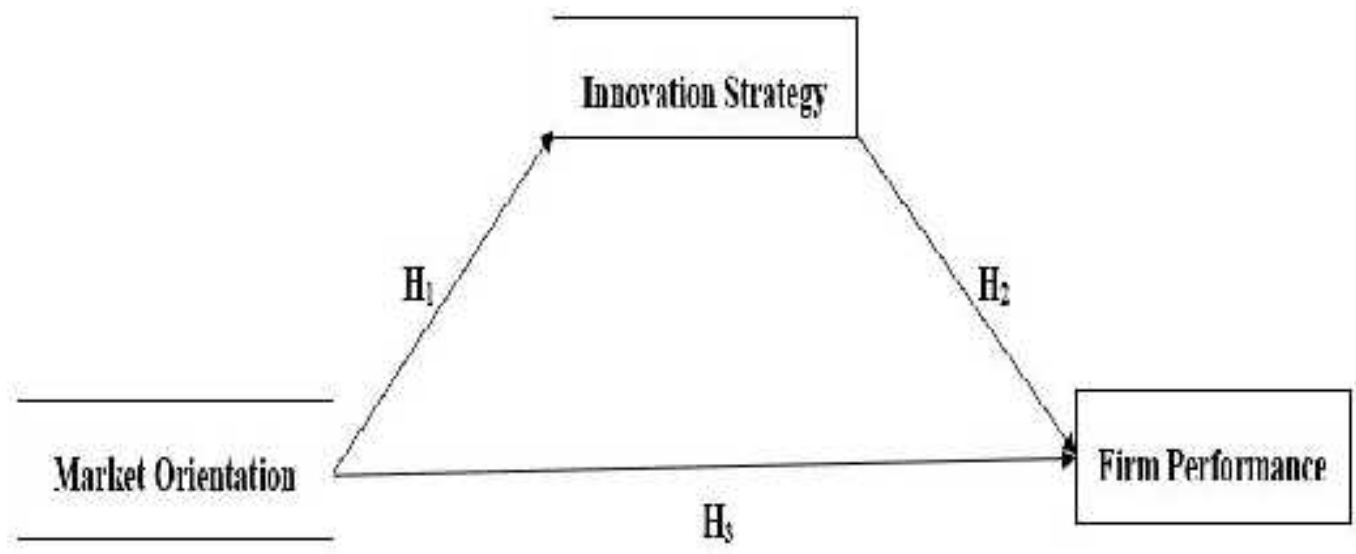

\section{METHODOLOGY}

This study collected data through distributing questionnaire among the employees working in corporate sector of Pakistan particularly from province of Punjab. In corporate sector 50 organizations that are high technology oriented and achieved excellence award in 2016 including fertilizer, pesticides, oil refinery, food and beverages etc. These organizations are highly innovative, efficient and face the challenge of surviving in dynamic environment and are more productive in their product and process development with industrial structured (Sexton \& Barrett, 2003; Dansoh, 2005). This study distributed and collected questionnaire from 240 employees working in twelve excellence awarding organizations from corporate sector. The respondents of this study are the full time regular (permanent) employees working in these firms including middle level managers and engineers.

The questionnaire was divided into four sections. In first section, the respondents asked questions regarding the construct of market orientation. Section two, the respondents asked questions about innovation strategy, Section three, the question regarding firm performance were asked. They also section were based on demographic information, Total 46 questions were asked in the questionnaire using 5 Likert Scale vary from 1= "strongly disagree" to $5=$ "strongly agree". Out of 46 questions, 15 questions used to measure the market orientation that was adopted from the study of Akman \& Yilmaz, (2008); 22 questions used to measure 
innovation strategy that was adopted from Gray et al. (1998) and 8 questions are used to measure the firm performance.

The model for this study was run and obtained the results using SPSS and Partial Least Square Structural Equation Modeling (PLS-SEM) version 3.2.4 softwares. The results for both measurement model and structural model were reported in next section. The results for demographic information were reported using SPSS.

\section{ANALYSIS/ RESULTS}

\begin{tabular}{|l|l|l|}
\hline Demographic Constructs & Count & Percentage \\
\hline Gender: & 225 & 93.8 \\
\hline Male & 15 & 6.3 \\
\hline Female & 115 & $47.9 \%$ \\
\hline Age: & 125 & $52.1 \%$ \\
\hline $\mathbf{2 1}$ to 30 & \multicolumn{2}{|l|}{} \\
\hline $\mathbf{3 1}$ to 40 & 0 & $0 \%$ \\
\hline Education & 207 & $86.3 \%$ \\
\hline Inter & 13 & $13.8 \%$ \\
\hline Graduate & & \\
\hline Master &
\end{tabular}

\subsection{Measurement Model Results}

This study reported the results of measurement model in Table 1.1. The showed the values for internal consistency reliability, convergent and discriminate validity.

This study reported internal consistency reliability through Cronbach's Alpha. The Cronbach's alpha value for market orientation is 0.832, innovation strategy is 0.901 and firm performance is 0.833. The Cronbach's Alpha values indicate high internal consistency reliability because the values are greater than 0.70 as suggested by Hair et al., (2014).

After this confirmatory factor analysis was perform to check the measurement model.

In order to test the model, we employed structural equation modeling. (SEM) using partial least squares (PLS) software. PLS is particularly interesting in the study for various reasons. Measurement model explains the factor loading of constructs measures, average variance extracted (AVE), construct reliability (CR) and Cronbach Alpha. In the measurement model, the indicators met the reliability and validity requirements. The results showed outer loadings of the indictors are greater than 0.60 that indicate that individual item reliability was adequate (Carmines \& Zeller, 1979). Secondly, all the reflective constructs met the construct reliability requirement as their composite reliabilities were higher than 0.7 (Nunnally \& Bernstein, 1994). Moreover, the results for latent variables achieved the convergent validity be requirement because AVE of construct are greater than 0.40 which indicated that the acceptable criteria for convergent validity. "Cronbach's alpha tends to provide a sever underestimation of the internal consistency reliability of latent variable in PLS path model". The results of composite reliability (CR) represent robustness in the terms of internal consistency reliability. The values obtained for CR presented acceptable level that range from 0.869 to 0.915 . 
Table 2 Measurement Model Results

Note: $F P=$ "Firm performance", $I S=$ "Innovation Strategy", $M O=$ "Market orientation" "AVE" Average Variance Extracted, "CR" Composite Reliability

Table 3 Factor Loading

Note: $F P=$ "Firm performance", IS= "Innovation Strategy", $M O=$ "Market orientation"

\begin{tabular}{|l|l|l|l|}
\hline Variables & FP & IS & MO \\
\hline FP1 & $\mathbf{0 . 7 4 9}$ & 0.685 & 0.028 \\
\hline FP2 & $\mathbf{0 . 6 8 9}$ & 0.613 & 0.108 \\
\hline FP3 & $\mathbf{0 . 6 2 8}$ & 0.539 & -0.103 \\
\hline FP4 & $\mathbf{0 . 7 2 3}$ & 0.675 & 0.079 \\
\hline FP5 & $\mathbf{0 . 6 9 0}$ & 0.714 & 0.151 \\
\hline FP6 & $\mathbf{0 . 6 3 4}$ & 0.629 & 0.120 \\
\hline FP7 & $\mathbf{0 . 6 4 9}$ & 0.616 & 0.037 \\
\hline FP8 & $\mathbf{0 . 6 6 8}$ & 0.633 & 0.114 \\
\hline IS7 & 0.447 & $\mathbf{0 . 5 3 6}$ & 0.060 \\
\hline IS8 & 0.546 & $\mathbf{0 . 6 2 5}$ & -0.080 \\
\hline IS9 & 0.542 & $\mathbf{0 . 6 0 5}$ & -0.103 \\
\hline IS10 & 0.723 & $\mathbf{0 . 6 7 5}$ & 0.079 \\
\hline IS11 & 0.690 & $\mathbf{0 . 7 1 4}$ & 0.151 \\
\hline IS12 & 0.634 & $\mathbf{0 . 6 2 9}$ & 0.120 \\
\hline IS13 & 0.649 & $\mathbf{0 . 6 1 6}$ & 0.037 \\
\hline IS14 & 0.559 & $\mathbf{0 . 6 6 3}$ & 0.046 \\
\hline IS15 & 0.626 & $\mathbf{0 . 7 0 5}$ & 0.112 \\
\hline IS16 & 0.668 & $\mathbf{0 . 6 3 3}$ & 0.114 \\
\hline IS17 & 0.654 & $\mathbf{0 . 6 8 0}$ & 0.060 \\
\hline IS18 & 0.546 & $\mathbf{0 . 6 0 6}$ & 0.048 \\
\hline IS19 & 0.605 & $\mathbf{0 . 6 4 8}$ & 0.100 \\
\hline IS20 & 0.509 & $\mathbf{0 . 5 8 3}$ & -0.020 \\
\hline IS21 & 0.559 & $\mathbf{0 . 6 1 6}$ & 0.026 \\
\hline IS22 & 0.529 & $\mathbf{0 . 6 1 3}$ & -0.028 \\
\hline MO1 & 0.027 & -0.002 & $\mathbf{0 . 6 2 8}$ \\
\hline MO2 & 0.016 & 0.031 & $\mathbf{0 . 5 4 5}$ \\
\hline MO5 & 0.094 & 0.072 & $\mathbf{0 . 8 2 0}$ \\
\hline MO8 & 0.004 & 0.011 & $\mathbf{0 . 5 7 1}$ \\
\hline MO9 & 0.069 & 0.061 & $\mathbf{0 . 7 5 9}$ \\
\hline MO10 & 0.111 & 0.078 & $\mathbf{0 . 7 8 1}$ \\
\hline MO14 & 0.037 & 0.028 & $\mathbf{0 . 6 6 8}$ \\
\hline & & & \\
\hline
\end{tabular}




\section{Table 4: Discriminant Validity}

\begin{tabular}{|l|l|l|l|}
\hline Variables & FP & IS & MO \\
\hline FP & $\mathbf{0 . 6 8 0}$ & & \\
\hline IS & 0.943 & $\mathbf{0 . 6 3 6}$ & \\
\hline MO & 0.104 & 0.080 & $\mathbf{0 . 6 8 9}$ \\
\hline
\end{tabular}

Note: $F P=$ "Firm performance", IS= "Innovation Strategy", $M O=$ "Market orientation" Fornell-Larcker criteria check the discriminant validity of the variables (Fornell \& Larcker 1981). This criteria test that the variance shared by the variable should be more than the variance shared with other variable items of a research model. Thus, the association of a variable with its own items measured through the taking square root of average variance extracted should be higher than the association between the variables measured in the model (Fornell \& Larcker 1981).

\subsection{Structural Model Results}

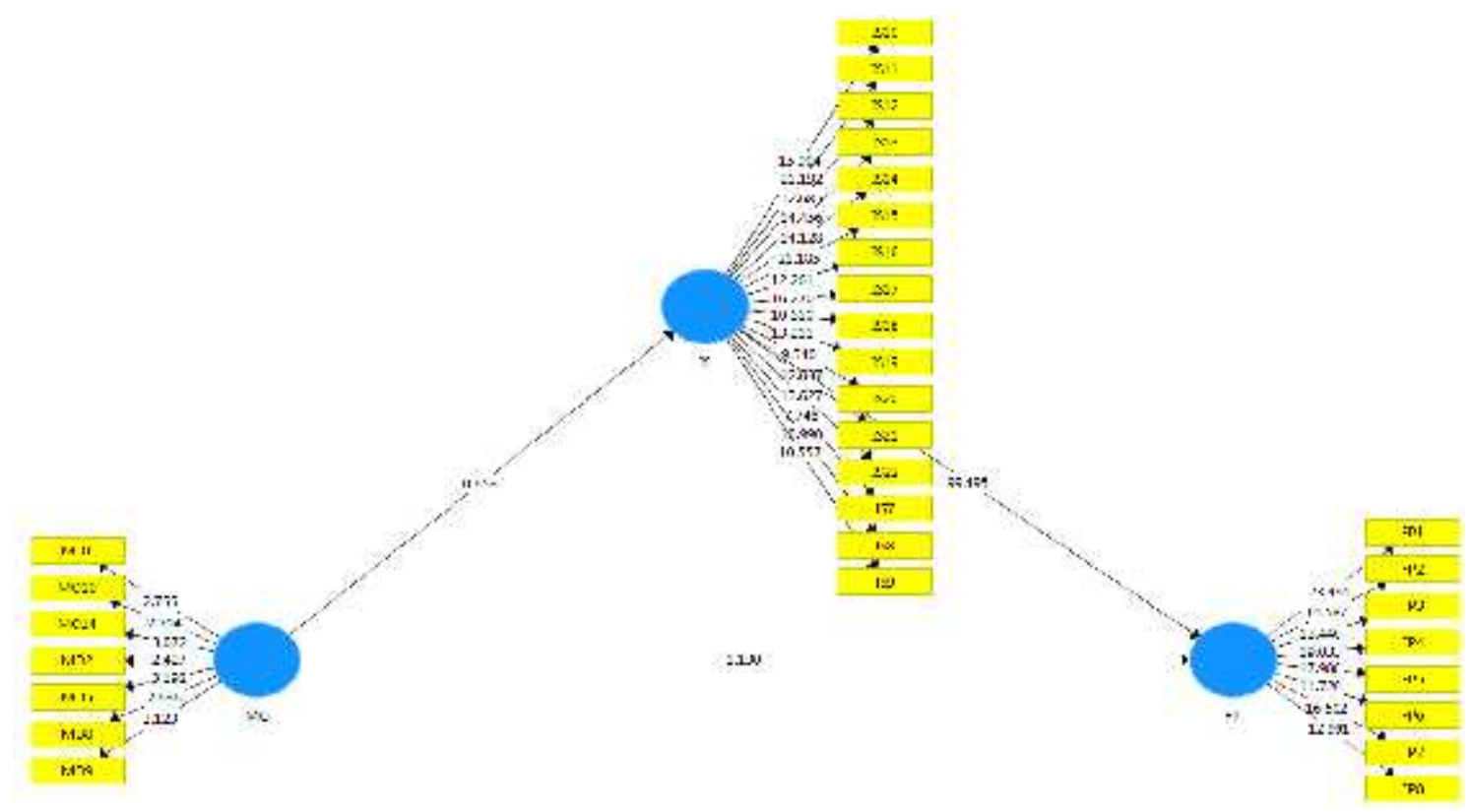

Note: FP= "Firm performance", IS= "Innovation Strategy", MO= "Market orientation" The structural model relationship was measured using PLS-SEM bootstrapping for the significance of the correlation. The number of cases used was 5000 sample for bootstrapping producer. The outcomes of the structural model indicates the positive relationship between innovation strategy and firm performance $(\beta=0.940, \mathrm{t}=99.495, \mathrm{p}$-value $=0.000)$. Therefore, hypothesis one strongly supported. Hypothesis two predicted that market orientation and firm performance $(\beta=0.029, \mathrm{t}=1.130, \mathrm{p}$-value $=0.259)$ this hypothesis is not supported. Market orientation and firm performance $(\beta=0.080, t=0.653, p=0.514)$ hypothesis two and three is not supported. 
Table 5: Result of the structural model analysis

\begin{tabular}{|l|l|l|l|l|l|}
\hline Hypothesis & Path & \multicolumn{1}{|l|}{ Path co-efficient } & t-statistic & P-value & Decision \\
\hline $\mathrm{H}_{1}$ & IS -> FP & $\mathbf{0 . 9 4 0}$ & $\mathbf{9 9 . 4 9 5}$ & $\mathbf{0 . 0 0 0}$ & Supported \\
\hline $\mathrm{H}_{2}$ & MO -> FP & $\mathbf{0 . 0 2 9}$ & $\mathbf{1 . 1 3 0}$ & $\mathbf{0 . 2 5 9}$ & Not Supported \\
\hline $\mathrm{H}_{3}$ & MO -> IS & $\mathbf{0 . 0 8 0}$ & $\mathbf{0 . 6 5 3}$ & $\mathbf{0 . 5 1 4}$ & Not Supported \\
\hline
\end{tabular}

Note: $F P=$ "Firm performance", IS= "Innovation Strategy", $M O=$ "Market orientation"

The results for mediation analysis indicate that innovation strategy does not mediates the relationship between market orientation and firm performance rather it has supported the direct relationship between innovation strategy and firm performance.

\section{DISCUSSION}

In this research paper, the effects of innovation strategies (aggressive strategy, analyzer strategy, futuristic strategy, proactive strategy, risk taking strategy and defensive strategy) examined with firm performance. It was investigated that these strategies are strongly effect on firm performance. One of the best finding of this research paper is proactive innovation strategy, proactive innovation strategy is highly encourages the firm performance (Akman \& Yilmaz, 2008). Proactive strategy has endorsed the firm toward innovation and suggests to do more innovation. Proactive strategy pursues the firm for the new opportunities and guided the organization for the innovation. Therefore, proactive strategy is most important for achieved the innovation which ultimately stimulates better firm performance. Futuristic strategy is another driver of innovation which pursue the firm for the diversity and development which ultimately stimulates the firm performance (Dansoh, 2005). In many past years, futuristic strategy was not highlighted for the improvement but it highlighted for risk and uncertainties situations. But in advance research, futuristic strategy becomes helpful to highlight the opportunities and threats which pursue the firm for the long term benefits and success (Akman \& Yilmaz, 2008). It help the organization for the opportunities exploitation, creating new ideas and shape these ideas into innovation. Other strategy that also influenced the organization performance development is analyzer strategy. Analyzer strategy is not influenced the firm performance directly but it guide various methods and techniques which required to recognized and exploit for the environmental change and be innovative (Entrialgo et al., 2000) Therefore, analyzer strategy is positively relationship with firm performance (Akman \& Yilmaz, 2008). Other important factor of the innovation strategy is aggressive strategy which influenced the firm performance very strongly and positively but its effects are not significant. For the successful implementation of aggressive strategy, organization provides flexible and structure investment, risk taking condition and apply analyzer strategy as a supplement. Other important factor is the risk taking strategy that have strong relationship with firm performance and there are positively relationship between risk taking and firm performance but the effects of risk taking and firm performance are not significant. This results indicators that's respondent did not reveal risk taking for the sustainable progress. In addition, risk taking strategy creates new methods and process which leads to firm performance (Akman \& Yilmaz, 2008). Other important factor is defensiveness strategy which has no significant relationship with firm performance. In our finding, among the six innovative strategies, the efficient strategies and proactive and 
futuristic strategies are the most effective strategies for the firm performance. However, the results regarding the relationship between market orientation and firm performance and also between innovation strategy and firm performance is not supported which indicates that the market orientation is less important for excellence awarding organization rather these organizations focused on their innovation strategies in order to get awards.

\subsection{Managerial Implication}

This study offers three major managerial implication. First of all, it is essential for the cooperation to understand the role of innovative strategy play as a central role for successful organization. Therefore, the factor that is very closely related with organization vision is innovation related strategies. It cover all the internal organizational strategies and external market and environmental strategies. Secondly, successful innovation strategy referred toknowledge, facts, learning, creativity and concept to change. Third, this study suggest that in case of activeness in their product, process and technology organization should futuristic and active in their policy making.

\subsection{Limitations and Future Research}

This research paper only concentrated only one group of the innovative strategy. Future research can be highlighted the other classification of innovative strategies such as innovative, follower, imitator etc. This research paper only concentrated only one group of the innovative strategy. Future research can be highlighted the other classification of innovative strategies such as innovators, followers, imitators etc. This study investigated the impact of market orientation and innovation strategies as mediator on firm performance Future studies should focus on moderator between the innovation strategy and firmperformance such as environmental uncertainty and dynamism effect.

\section{REFERENCE}

Akhlagh, E. M., Moradi, M., Mehdizade, M., \& Ahmadi, N. D. (2013). Innovation strategies, performance diversity and development: An empirical analysis in ran construction and housing industry. Iranian Journal of Management Studies, 6(2), 31.

Akman, G., \& Yilmaz, C. (2008). Innovative capability, innovation strategy and market orientation: an empirical analysis in Turkish software industry. International Journal of Innovation Management, 12(01), 69-111.

Atuahene-Gima, K., \& Ko, A. (2001). An empirical investigation of the effect of market orientation and entrepreneurship orientation alignment on product innovation. Organization science, 12(1), 54-74.

Atuahene-Gima, K. (1996). Market orientation and innovation. Journal of business research, 35(2), 93-103.

Bessant, J., \& Tidd, J. (2009). Inovação e empreendedorismo: administração. Bookman Editora.

Bayraktar C. A, Hancerliogullari G, Cetinguc B., \& Calisir F. (2016). Competitive strategies, innovation, and firm performance: an empirical study in a developing economy environment, Technology Analysis and Strategic Management, pp. 38-52

Chin, C., Grimm, R., Julienne, P., \& Tiesinga, E. (2010). Feshbach resonances in ultracold gases. Reviews of Modern Physics, 82(2), 1225.

Carmines, E. G., \& Zeller, R. A. (1979). Reliability and validity assessment (Vol. 17). Sage publications. 
Calantone, R. J., Cavusgil, S. T., \& Zhao, Y. (2002). Learning orientation, firm innovation capability, and firm performance. Industrial marketing management, 31(6), 515-524.

Cooper, R. G., Edgett, S. J., \& Kleinschmidt, E. J. (2004). Benchmarking best NPD practices-III. Research-Technology Management, 47(6), 43-55.

Chandy, R. K., \& Tellis, G. J. (1998). Organizing for radical product innovation: The overlooked role of willingness to cannibalize. Journal of marketing research, 474-487.

Entrialgo, M., Fernández, E., \& Vázquez, C. J. (2000). Characteristics of managers as determinants of entrepreneurial orientation: some Spanish evidence. Enterprise and innovation management studies, 1(2), 187-205.

Länsiluoto, A., Joensuu-Salo, S., Varamäki, E., Viljamaa, A. and Sorama, K. (2018), Market orientation and performance measurement system adoption impact on performance in SMEs. Journal of small business management. doi:10.1111/jsbm.12393

Fruhling, A. L., \& Siau, K. (2007). Assessing organizational innovation capability and its effect on e-commerce initiatives. Journal of Computer Information Systems, 48(1), 133-145.

Fornell, C., \& Larcker, D. F. (1981). Structural equation models with unobservable variables and measurement error: Algebra and statistics. Journal of marketing research, 382388.

Gatignon, H., \& Xuereb, J. M. (1997). Strategic orientation of the firm and new product performance. Journal of marketing research, 77-90.

Gearing, A. J., Beckett, P., Christodoulou, M., Churchill, M., Clements, J., Davidson, A. H., ... \& Gordon, J. L. (1994). Processing of tumour necrosis factor-alpha precursor by metalloproteinases. Nature, 370(6490), 555.

Gupta, V., MacMillan, I. C., \& Surie, G. (2004). Entrepreneurial leadership: developing and measuring a cross-cultural construct. Journal of business venturing, 19(2), 241-260.

Haefner, Naomi \& Palmié, Maximilian (2017) "With(out) a Little Help From My Friends? Stakeholder Management, Innovation Strategy, and Long-Term Firm Performance". In: 23rd Annual Organization Science Winter Conference, 2-5 Feb 2017, Park City, UT.

Hjelmesaeth, J., Sagedal, S., Hartmann, A., Rollag, H., Egeland, T., Hagen, M., ... \& Jenssen, T. (2004). Asymptomatic cytomegalovirus infection is associated with increased risk of new-onset diabetes mellitus and impaired insulin release after renal transplantation. Diabetologia, 47(9), 1550-1556.

Hult, G. T. M., Hurley, R. F., \& Knight, G. A. (2004). Innovativeness: Its antecedents and impact on business performance. Industrial marketing management, 33(5), 429-438.

Jenssen, J. I., \& Randøy, T. (2002). Factors that promote innovation in shipping companies. Maritime Policy \& Management, 29(2), 119-133.

Jenssen, J. I., \& Nybakk, E. (2009). Inter-organizational innovation promoters in small, knowledge-intensive firms. International Journal of Innovation Management, 13(03), 441-466.

Jones, G. K., \& Lanctot, J. R. (2000). A, Teegen HJ. Determinants and Performance Impacts of External.

Lendel, V., \& Varmus, M. (2011). Creation and implementation of the innovation strategy in the enterprise. Economics and management, 16, 819-825.

Love, P. E., \& Irani, Z. (2003). A project management quality cost information system for the construction industry. Information \& Management, 40(7), 649-661.

Maltz, A. C., Shenhar, A. J., \& Reilly, R. R. (2003). Beyond the balanced scorecard:: Refining the search for organizational success measures. Long Range Planning, 36(2), 187-204. 
Mavondo, F. T., \& Farrell, M. A. (2000). Measuring market orientation: are there differences between business marketers and consumer marketers?. Australian journal of management, 25(2), 223-244.

Mariadoss, B. J., Tansuhaj, P. S., \& Mouri, N. (2011). Marketing capabilities and innovationbased strategies for environmental sustainability: An exploratory investigation of B2B firms. Industrial Marketing Management, 40(8), 1305-1318.

Micheels, E.T. and Gow, H. (2012). The effect of alternative market orientation strategies on firm performance, International journal of marketing studies, 4(3), 2-15.

Miles, R. E., \& Snow, C. C. (2007). Organization theory and supply chain management: An evolving research perspective. Journal of operations management, 25(2), 459-463.

Najib, M. F., Kartini, D., Suryana, Y., \& Sari, D. (2017). Market orientation, buyer-supplier relationship and firm performance with dynamic capabilities as an intervening variable: a research model. International journal of business and globalisation, 19(4), 567-582.

Narver, J. C., \& Slater, S. F. (1990). The effect of a market orientation on business profitability. The Journal of marketing, 20-35.

Nambisan, S. (2002). Designing virtual customer environments for new product development: Toward a theory. Academy of Management Review, 27(3), 392-413.

Wheelwright, S. C., \& Clark, K. B. (1992). Revolutionizing product development: quantum leaps in speed, efficiency, and quality. Simon and Schuster.

Vázquez, R., Santos, M. L., \& Álvarez, L. I. (2001). Market orientation, innovation and competitive strategies in industrial firms. Journal of strategic marketing, 9(1), 69-90.

Venkatraman, N. (1989). The concept of fit in strategy research: Toward verbal and statistical correspondence. Academy of management review, 14(3), 423-444. 